\title{
Author Correction: Super-resolution microscopy compatible fluorescent probes reveal endogenous glucagon-like peptide-1 receptor distribution and dynamics
}

Julia Ast (10, Anastasia Arvaniti, Nicholas H. F. Fine (D), Daniela Nasteska (D), Fiona B. Ashford, Zania Stamataki (D), Zsombor Koszegi, Andrea Bacon, Ben J. Jones, Maria A. Lucey, Shugo Sasaki (D, Daniel I. Brierley (D, Benoit Hastoy (1), Alejandra Tomas, Giuseppe D'Agostino (1), Frank Reimann (1), Francis C. Lynn (1), Christopher A. Reissaus, Amelia K. Linnemann (D), Elisa D'Este, Davide Calebiro (D), Stefan Trapp (D), Kai Johnsson (1), Tom Podewin (D), Johannes Broichhagen (1) \& David J. Hodson (1)

Correction to: Nature Communications https://doi.org/10.1038/s41467-020-14309-w, published online 24 January 2020.

The original version of this Article contained an error in the Methods section, when reporting ethical approval related to the generation of hESCs, which read: 'hESC (WA01/H1; hPSCreg name WAe001-A) (obtained from WiCell) were generated by the originating institute with informed consent and ethical approval from the Robert-Koch Institut, Berlin (Az.3.04.02/0101) and NIH (NIHhESC-100043). Studies with hESC (WA01/H1) were approved by the BC Children's and Women's Hospital Human Research Ethics Board (Approval \#H09-00676)'. However, the cells were purchased from WiCell (Wisconsin) and the Robert-Koch Institute and NIH were not involved in the study. The sentence has now been corrected to state: 'hESC (WA01/H1; hPSCreg name WAe001-A) were purchased from WiCell (Wisconsin) (full details including ethics and informed consent available at hPSCreg, cell line WAe001-A). Studies with hESC (WA01/H1) were approved by the BC Children's and Women's Hospital Human Research Ethics Board (Approval \#H09-00676)'. This has been corrected in both the PDF and HTML versions of the Article.

Published online: 09 October 2020

\footnotetext{
(c) (i) Open Access This article is licensed under a Creative Commons Attribution 4.0 International License, which permits use, sharing, adaptation, distribution and reproduction in any medium or format, as long as you give appropriate credit to the original author(s) and the source, provide a link to the Creative Commons license, and indicate if changes were made. The images or other third party material in this article are included in the article's Creative Commons license, unless indicated otherwise in a credit line to the material. If material is not included in the article's Creative Commons license and your intended use is not permitted by statutory regulation or exceeds the permitted use, you will need to obtain permission directly from the copyright holder. To view a copy of this license, visit http://creativecommons.org/licenses/by/4.0/.
}

(c) The Author(s) 2020 